\title{
Un dramaturg din ,provincie” către centru: Victor Cilincă
}

\author{
Asist. univ. dr. BOTEZATU Elena \\ Universitatea „Dunărea de Jos” din Galați
}

\begin{abstract}
The dramatic works by Victor Cilincă (born on January 15, 1958 in Pașcani, Iași County) display an obvious intention of nearing the "grand texts" of world literature, in his own manner, of course, by anchoring the view in "the present lived". Out of the many titles which make up the playwright's complete works ascribable to the aforesaid grid, one could mention: O scrisoare... Găsită [A... Found Letter], Dulcețuri și otrăvuri sau D'ale Caragialelui [Sweets and poisons, or Caragialesques], Generalul generalilor [The Generals' General] - with another version, Waiting for... Godeaux, Țara / Tzara de sub picior [The Land/ Tzara under the Foot], Romică și Jeanette or, why not, Zimbrul păcălit de vulpe [The Aurochs fooled by the Fox]. Another "dialogue" constructed around a character, around a dominating human type, can be established between Cilincă's play Paparazzi and the homonymous play by Matei Vișniec. The parallel analysis of the two plays relies on observing the "relation between texts" and the way in which the figure of the journalist is outlined by the two playwrights.
\end{abstract}

Keywords: drama, patterns, "dialogue of texts", centre, periphery.

Născut pe data de 15 ianuarie 1958 la Pașcani, județul Iași, stabilit ulterior la Galați, despre Cilincă se poate spune că este un autor din „provincie”, dar unul mândru de „nestrămutarea sa” ${ }^{10}$. După cum însuși mărturisește, prin anii 80, găsea până și Bucureștiul a fi undeva „departe și foarte sus”, crezând că pentru a viza capitala, ca scriitor, trebuia „să fii într-o anumită zodie, specială"11. Chiar dacă (re)cunoașterea creațiilor sale s-a concretizat mai târziu, acestea nu fac altceva decât să demonstreze, de la primele scrieri, depășirea a ceea ce este adesea numit "complexul margine-centru", tocmai prin constantul dialog cu marile texte ale lumii, prin reflectarea „nostalgiilor unor alte lumi”. Despre această caracteristică a operei sale dramatice, referindu-se la piesele Polonius și Să lingem zidu'! sau Fetița cu brichetă ${ }^{12}$, Mircea Ghițulescu observa „mersul la

\footnotetext{
10 „,Aparțin spațiului (cultural) gălățean!", n. a., corespondență (2015).

${ }^{11}$ Ibidem.

12 Premiera monodramă în cinci „flăcări” a avut loc în cadrul Festivalului Naţional de Teatru „Gong Fest” din Reşiţa în mai 2013, montată de Teatrul independent DA, în regia
} 
braț" cu Shakespeare și Andersen, punctând șansele reduse ale dramaturgului de „a greși” ${ }^{\prime \prime}$. Mirajul spațiilor-centru apare ca o constantă în creațiile autorului. Spre exemplu, într-un scenariu (în curs de apariție), doi tineri, ce voiau să plece din țară, sunt păcăliți că se află în drum spre Italia. Fiind tot în România, dar necunoscând acele locuri, își exprimă încântarea: „Ce frumos e!, Ce copaci!, Ce mănăstiri!... E diferit!” etc. Însă, când ajung să simtă lipsurile, exclamă: „Ce bine era la noi!”14. În Europa pe de rost, Adam întreabă: „Unde vine asta, Ieuropa?

OMUL CUNOSCUT (mirat): - Ei, hai, hai, du-te dracu' ! Cum, «unde-i Europa?» Păi, orice copil ştie cam pe unde-i Europa, bre! E... (arată cu degetul spre stânga, se gândeşte puţin, apoi arată spre sală) Uite - Europa! Pe-acolo e! (către cineva din sală) Vezi dom'le că stai cu spatele la ea! (arată obrazul) Vezi, că nu-i frumos! (...). E altceva... Toată lumea vorbeşte de ea, spune că vrem să intrăm în ea, sau că am intrat, sau că o să ieşim, dar nu cred să ştie prea mulți pe unde vine exact, cum e să trăieşti acolo, cum fac ăia mămăliga..."15.

Figurând în secțiunea de „dicționar" a istoriei realizate de criticul teatral, „curriculum-ul literar" al lui Cilincă însumează peste treizeci de opere de teatru, inclusiv piese pentru copii. Dintre titluri, în afară de cele deja numite, mai pot fi menționate: Catrafuse sau Fany ${ }^{16}$, Moarte bună! sau Domnu' de la ziar17, Off sau Regele schimbărilor18, Generalul-Generalilor sau Merci, Berthelot!19 ș.m.a. Referinduse la Moarte bună!, același Ghițulescu preciza: „El (autorul) este pe un drum

lui Dan Mirea. Mircea Ghițulescu o consideră „,textul său major, în afară de Polonius”, în Istoria literaturii române. Dramaturgia, Editura Academiei Române, București, 2007, p. 815. 13 V. Mircea Ghițulescu, Istoria literaturii române. Dramaturgia, Editura Academiei Române, București, 2007, pp. 814-816.

14 *** Corespondență (2015).

15 Victor Cilincă, Europa pe de rost (piesă nepublicată încă), pp. 11-12.

16 Piesa despre actrița Fani Tardini (sau Fany Tardiny / Tardinny- după cum îi apărea numele în gazetele vremii) a fost nominalizată la categoria „Cea mai bună piesă a anului" la Gala UNITER din 2007 și publicată în 2010.

${ }^{17}$ Reprezentarea s-a realizat sub forma unui spectacol-lectură în regia lui Attila Vizauer, în cadrul "Clubului Dramaturgilor", sub egida Uniunii Scriitorilor din România în 2009.

18 Piesa a fost legată în volum în 2011 și montată în premieră la Teatrul Dramatic din Galați în stagiunea 2014-2015 sub numele de Viață de schimb.

${ }^{19} \mathrm{Cu}$ alte variante de titlu, precum: Războiul se amână! sau Strecurătoarea sau Gloanțe, vise și gunoaie sau Așteptându-l pe ... Godeaux sau Generalii sau Taica Bertălău. După cum se poate observa, procesul de alegere a „cuvântului" este amplu, dramaturgurgul căutând să ,"amprenteze răsunător" textele sale. Piesa a fost reprezentată sub formă de scenariu radiofonic sub coordonarea lui Attila Vizauer pe data de 30 iunie 2015. 
foarte bun. Dacă şi dramaturgia românească ar fi pe un drum foarte bun, el ar fi fost o celebritate în ziua de astăzi. Dar cum dramaturgia nu este pe un drum foarte bun, se mulţumeşte şi el cu situaţia de ziarist ${ }^{20}$. (...) Din punct de vedere al tehnicii comediografice, este foarte bine pusă la punct. Are poantele unde trebuie, punctate când trebuie" 21 . Pe lângă acestea, dramaturgul consideră că a încercat „mai tot ce se putea”: scenarii de film², texte în proză ${ }^{23}$, dar și poezie. Ca membru al Uniunii Ziariştilor Profesionişti din România ${ }^{24}$, a realizat numeroase editoriale (unele chiar în versuri), implicare ce l-a ajutat să simtă constant „pulsul vieții”. Chiar și la o scurtă privire retrospectivă, parcursul său existențial se dovedește a fi unul interesant. Cândva „om al apelor" 25, Cilincă își amintește de emoția și de impulsul creator simțite la călcarea meleagurilor africane, căci, acolo, Saint-Exupéry fusese comandant de escadrilă. Acesta mărturisește că, pe când era scafandru, a scrijelit poeme inclusiv pe chila navelor, sub apa Atlanticului. Pasiunea pentru istorie se reflectă în scrierile sale, o parte a teatrului său fiind încadrată celui „de evocare” ${ }^{26}$. Cu studii liceale în

${ }^{20}$ Cilincă precizează: „În general, nu se poate trăi din scris... Iisus a fost tâmplar, alții, șlefuitori... eu, jurnalist", corespondență (2015).

${ }_{21}$ V. Marius Țuca, Emoții și elogii pentru Victor Cilincă, în Viața liberă, Galați, 2 iunie 2009, n. a., disponibil online: http://www.viata-libera.ro/vlg-cultura/6372-emotii-si-elogiipentru-victor-cilinca.

${ }^{22}$ Toate relele și la locul lor, Out of Romania ș. a. Nota autorului, pentru cel din urmă scenariu, punctează: „Imaginile poveştii de dinainte de 1989 sunt filmate în culori (uşor decolorate), cele de după 1989, în alb-negru", p. 1663 dintr-un volum (amplu) în curs de publicare, corespondență 2015.

${ }^{23}$ Dintre multele creații, se impun menționate: romanul foileton Zaraza, publicat în 1997 în cotidianul Viața liberă sub pseudonimul Irena Mow Stoica și PUSH-PUSH! sau Îngeri ordinari. Roman de sertar, Editura N'ERGO, Galaţi, 2002; v. Constantin Trandafir, Prozatorul Victor Cilincă, în Porto-Franco, nr. 228, Galați, 2015, pp. 102-103.

${ }^{24}$ A se vedea contribuțiile din paginile unor reviste de cultură precum: Miracol (Bucureşti), Millenium, Boem@ (Galaţi) ș.a.

${ }^{25}$ V. și Victor Cilincă, Odiseea pentru uz intern - roman despre viaţa marinarilor -, Ed. Logos, Galați, 1997.

26 Dacă Ghițulescu semnala urmele procesului de documentare în detrimentul ingeniozității, Cilincă afirmă: „Eu nu fac piese istorice pur și simplu, de evocare, ci cu trimiteri la niște idei. (...) În calitate de critic, Ghițulescu a preferat o linie de mijloc, sigură. Mie îmi vorbea foarte cald despre piesele mele, dar, când a trebuit să scrie, a fost, poate, mai mult decât "temperat”, dorind ca, odată cu trecerea timpului, lumea să nu vadă / să nu creadă că s-a înșelat... Totuși, notabilă includerea mea în Istorie...", 
domeniul artelor, Cilincă semnează caricatură, desenându-și adesea ilustrațiile de pe coperțile cărților publicate. Plăcerea autorului de a se juca cu cititorul, ca „formă de manifestare a respectului purtat”27, nu se observă doar la nivel textual, ci și la nivel formal. Pe lângă încercarea de a îmbunătăți monocromia tipografică prin înlocuirea negrului cu brun închis, verde de China sau albastru de Prusia, un alt exemplu îl constituie volumul de teatru Paparazzi. Polonius. Coperta a IV-a este înlocuită cu una „de deschidere”, căci cele două piese sunt tipărite „răsturnat”, cu o numerotare separată a paginilor ${ }^{28}$.

Chiar și la o scurtă „privire”, creațiile dramatice ale lui Victor Cilincă indică un joc inedit ${ }^{29} \mathrm{cu}$ „marile modele" ale literaturii universale, amintind parcă de ceea ce Bernard Dort îi spusese lui George Banu ${ }^{30}$, odată ajuns în Franța: „Ați citit aceleași cărți ca noi!”31. Dintre numeroasele titluri ce compun opera dramaturgului și care se pot înscrie grilei mai sus menționate, pot fi evidențiate: O scrisoare... găsită, Dulcețuri și otrăvuri sau D'ale Caragialeluỉ², Generalul generalilor - cu o altă variantă, Așteptându-l pe ... Godeaux³3, Țara / Tzara de sub picior ${ }^{34}$, Romică și Jeanette ${ }^{35}$, dar și, de ce nu, Zimbrul păcălit de vulpe $e^{36}$. Un alt "dialog", construit în jurul unui personaj, în jurul unei tipologii umane ce pare a

corespondență (2015).. De altfel, Cilincă este membru al Asociației Profesorilor de Istorie „Dunărea de Jos” din Galați.

${ }^{27}$ Victor Cilincă, corespondență (2015).

${ }^{28}$ V. Victor Cilincă, Paparazzi. Polonius, Editura Dominus, Galați, 1999.

29 *** Dialogul neîntrerupt al teatrului în secolul XX (vol. I, De la Caragiale la Brecht; vol. II, De la Lorca la Brook), București, Editura Minerva, 1973.

${ }^{30}$ V. Iulian Băicuș, Critici literari români din diaspora, Editura Virtual, București, 2013.

${ }^{31}$ Citatul integral continua cu „- el nu știa cu ce eforturi!", în George Banu, Ultimul sfert de secol teatral. O panoramă subiectivă, trad. de Delia Voicu, Editura Paralela 45, București, 2003, p. 5.

32 Piesă-evocare „după diferite mărturisiri scrise şi vorbite ale lui Ion Luca Caragiale şi ale altora despre nenea Iancu", ce a obținut premiul al III-lea la Festivalul Naţional de Dramaturgie - Comedie, organizat la Teatrul Dramatic „Fani Tardini” din Galați în 2012 (nepublicată încă).

33 În afară de Ultimul Godot al lui Matei Vișniec, personajul lui Beckett apare și ca "Godieu", în Îngerul bătrîn al lui Alexandru Sever.

${ }^{34}$ V. Matei Vișniec, Omul din care a fost extras răul, Editura Cartea Românească, București, 2014, cuprinzând, pe lângă piesa ce dă numele volumului, De ce Hecuba și Cabaretul Dada (în vrac și în lucru permanent). În cea din urmă, se distinge dialogul dintre Domnul Dada și Tristan Tzara.

35 "Autohtonizare" a piesei Romeo și Jeanette de Jean Anouilh.

${ }^{36} \mathrm{Cu}$ personaje alegoric-antagonice: Poetul (Ion) Zimbru, Micul Prins (nu Micul Prinț). 
domina "prezentul”, se poate stabili între piesa Paparazzi a lui Cilincă și cea cu același titlu, aparținându-i lui Matei Vișniec. Analiza în paralel a acestor opere dramatice are la bază intenția observării „relației dintre texte”, a felului în care o figură, a omului de presă în cazul de față, este conturată între doi dramaturgi.

În septembrie 1997, Paparazzi sau Cronica unui răsărit de soare avortat ${ }^{37}$ a lui Vişniec era montată în premieră la Teatrul „La Maison des Comoni” din Revest-les-Eaux (Toulon). Tot atunci, Victor Cilincă începea crearea unui alt Paparazzi, subintitulat și Gigi sau Șacal cu Pedigree sau Șacalul sau Tulburătoare poveste de dragoste: între un bărbat și o femeie! ${ }^{38}$. Coperta I a volumului în care e inclus cel din urmă text dramatic, sugerând evenimentul de la care "s-a pornit" scrierea, înfățișează o poză a prințesei de Wales, precum și sentința dată în cazul fotoreporterilor ce o urmăreau în seara tragicului accident: „Vor fi acuzați de ucidere din culpă". Dacă Vișniec creează Clovnii impresionat fiind de cei ai lui Fellini, Cilincă alege drept motto pentru piesa sa o replică din filmul La dolce vita, „Paparazzo, basta!”. Un mesaj similar, de tragere a unui „semnal de alarmă”, este dezvoltat de autorul stabilit în spațiul francez în articolul Astăzi nu sînt știri din Cronica ideilor tulburătoare. Punctând caracteristica ",aberantă” atât a comportamentului cititorului de presă sau a telespectatorului, cât și a celor „care ne pregătesc și ne difuzează știrile”, Vișniec aseamănă tendința presei „actuale”, în linii mari, cu una de „spălare de creiere” ${ }^{39}$. Odată cu lansarea piesei în România, Iulia Popovici nota că „experiența comunismului i-a întors lui Vişniec ochii spre exterior, spre societate" ${ }^{40}$. Observația avea să fie „întărită” de

\footnotetext{
37 Scrisă inițial în franceză în 1996, a fost publicată în 1997 la Editura Actes Sud-Papiers din Paris. Un fragment, în româneşte, a fost inclus în revista Okean, nr. 1 din aprilieiunie 2000. Textul integral a apărut în 2000 la editura electronică LiterNet, fiind disponibil online: http://editura.liternet.ro/carte/20/Matei-Visniec/PAPARAZZI-sauCronica-unui-rasarit-de-soare-avortat.html; V. impresiile unui spectator în urma unei montări a piesei în România în Mircea Morariu, Cronică de teatru: Un clar-obscur multisemantizat, în Adevărul, 1 martie 2013, disponibil online: http://adevarul.ro/cultura/teatru/cronica-teatru-clar-obscur-multisemantizat1 5130b4f200f5182b85b9512d/index.html.

38 Piesa a fost finalizată în 1998 și publicată în volum alături de Polonius la Editura Dominus din Galați, în 1999.

${ }^{39}$ Matei Vișniec, Cronica ideilor tulburătoare, Editura polirom, București, 2010, pp. 21-23. În piesa lui Victor Cilincă, apare, de asemenea, o replică: „Cu pixu’ și televizoru' / ați mințit poporu'!” (Geta), în Paparazzi. Polonius, Editura Dominus, Galați, 1999, p. 45.

${ }^{40}$ Iulia Popovici, Lecturi la zi: Din nou, Vişniec, în România literară, nr. 44, 2002, disponibil online: http://www.romlit.ro/din nou viniec.
} 
dezvoltarea aceleiași tematici de către dramaturg în Istoria comunismului povestită pentru bolnavii mintal41. Implicarea ambilor scriitori în activitatea jurnalistică își pune amprenta asupra operelor în discuție, căci viziunile „din interior" se întretaie în creații, prin dezvăluirea de lumi în derivă.

Prologul și epilogul piesei lui Cilincă înfățișează accidente la care se întâmplă să asiste doi paparazzi. Dialogul dintre aceștia evidențiază dezumanizarea celor ce și-au ales o astfel de „îndeletnicire”, explicând, totodată, încadrarea lor în categoria ,șacalilor":

„PRIMUL NECUNOSCUT: - Parfum! Aveam ce scrie o săptămână! (...)

AL DOILEA NECUNOSCUT: - Poate iese ceva, dac-a călcat un om. Înseamnă că n-am pierdut timpu' degeaba pe şosea..." ${ }^{42}$. Scenele ce includ moartea sunt marcate, la nivelul simbolurilor comune, de o prezența câinele. Fotoreporterilor din Şacalul li se pare întotdeauna, inițial, că mașinile lovesc câini „mari”. Paparazzo 2 din Cronica unui răsărit de soare avortat vede același animal sinucigându-se, dar privindu-1 „în ochi" ${ }^{43}$. Semnificând fie valoarea scăzută a ființei umane în cadrul imaginat, fie pierderea "afecțiunii”, a umanității, (sin)uciderea elementului animalier anunță un „apus perpetuu al fiecăruia” 44 .

Tragismele sunt preferate și de „oamenii” lui Vișniec, după cum reiese și din secvența în care profesorul de astronomie Pandolfi, legat într-un sac, este lovit constant. De altfel, într-o astfel de societate, „imaginea tinde sa înlocuiasca cuvântul" ${ }^{45}$ :

„PAPARAZZO 2: Păi, ți-am zis, el nu face nimic, se zbate din când în când și geme. Asta-i tot. Te interesează, șefu'? Am făcut câteva poze, dar nu știu dacă să mai stau...

${ }^{41}$ Matei Vișniec, Istoria comunismului povestită pentru bolnavii mintal, Editura LiterNet, 2003,. disponibil online: http://editura.liternet.ro/carte/50/Matei-Visniec/Istoriacomunismului-povestita-pentru-bolnavii-mintal.html.

42 Victor Cilincă, Paparazzi. Polonius, Editura Dominus, Galați, 1999, p. 6.

${ }^{33}$ Matei Vișniec, Paparazzi sau Cronica unui răsărit de soare avortat, Editura LiterNet, 2002, p. 27.

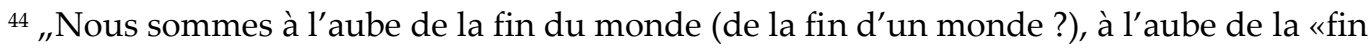
de chacun»" în Matei Vișniec, Paparazzi ou La Chronique d'un lever de soleil avorté. Présentation, disponibil online: http://www.visniec.com/pages/paparazzi.php.

45 Daniela Boboiciov Magiaru, Interviu cu Matei Vișniec. Utopia si practica. Un raport pervers, în Orizont, Nr. 1, ianuarie 2007, disponibil online: http://www.romaniaculturala.ro/articol.php?cod=7548. 
VOCEA ȘEFULUI: Ar merita să-i mai faci niște poze numai dacă îl omoară cumva... când or să-l omoare. Dar verifică întâi dacă e om politic sau nu" 46 . Interogatoriile la care sunt supuși răniții exclud solidaritatea umană, întrajutorarea celor aflați în situații limită, deoarece meseria „nu permite”:

„PAPARAZZO 2: (...) Ascultați-mă cu atenție, domnule. Eu sunt jurnalist. Eu nu am dreptul să intervin în nici un fel niciodată, nicăieri. Eu nu fac decât să informez în mod obiectiv. Înțelegeți? Deci, dacă sunteți de acord, eu vă scot călușul de la gură pentru câteva secunde atât cât puteți să-mi spuneți cum vă cheamă și ce profesiune aveți. Da? Dar nimic mai mult, înțelegeți? Și după aceea, vă pun călușul la loc, pentru că eu nu am voie să ating nimic" ${ }^{47}$. Aceeași „imposibilitate de acțiune" se remarcă și în textul dramaturgului gălățean. Chiar dacă victima este „aranjată" pentru poză, nu se poate chema medicul, fiind așteptat, mai degrabă, polițistul, spre a constata decesul:

„AL DOILEA NECUNOSCUT (îl întoarce pe Rănit pentru că nu-l prinde bine în obiectiv): Hai, copăcel, că n-o să ieşi frumos în pagină. Bârrr, cât sânge! (...)

PRIMUL NECUNOSCUT: Nu mă pricep să dau primul ajutor. (Cu obidă) Noi suntem ăia care dăm ULTIMUL AJUTOR! Ştiai că eşti un paparazzi?" 48 . Subordonarea faţă de conducere, într-o astfel de meserie, este esențială: „Trebuie să ştie şefii noştri. Pentru că, vorba aia, «Scrii ce vezi... da' vezi ce scrii!» (...) Eu intru şi prin ziduri!"49. Angajat la ziarul „Media”, Mutu', paparazzo în curs de afirmare, apreciează concurența pentru „neclintire”: „Ai văzut că în «Viitorul» nu apare aproape niciodată drept la replică? Sunt profesionişti, nu ca noi!"50. Bun cunoscător al domeniului, își amintește de încercarea eșuată a unui absolvent de Litere de a se angaja. Ținut de vorbă intenționat cât s-a petrecut un alt accident, acesta a nu a putut reproduce evenimentele „din spate":

MUTU': S-a prezentat ieri unu', cu (...) tot tacâmu, cu pedigree...

GETA: - Ce-i soro aia, «pedigrii»?

MUTU': - Adică avea «rasă», sânge bleo!"

GETA: - Şi l-a luat?

\footnotetext{
${ }^{46}$ Matei Vișniec, Paparazzi sau Cronica unui răsărit de soare avortat, Editura LiterNet, 2002, p. 57, s. a.

${ }^{47}$ Ibidem, p. 60.

${ }^{48}$ Victor Cilincă, Paparazzi. Polonius, Editura Dominus, Galați, 1999, pp.: 7, 56.

${ }^{49}$ Ibidem, pp. 41-42.

${ }^{50}$ Ibidem, p. 52.
} 
MUTU': - Aş! (...) (îl imită): «Păăi... păăăi, nu m-aţi lăsat să văd!». Nea Jean s-a uitat aşa, cu milă la el, şi i-a zis blând: «Pe-un ziarist adevărat, nimic nu-1 opreşte să întoarcă capul. Nici dacă îl are în ghips!»" 51 .

În ciuda faptului că nu lipsesc „cu desăvârșire”, fărâmele de umanitate nu par a fi suficiente pentru a asigura o salvare. Pasiunea unuia dintre cei doi „necunoscuți” de a imortaliza copaci „mișto” se întretaie cu surprinderea de "țeste sparte". Povestea de iubire dintre Gigi și Paul, chiar dacă ingenios clădită, inclusiv prin declarația metaforică a bărbatului ${ }^{52}$, nu anticipă un „alt viitor", mai bun, deoarece ocupația acestuia îl înscrie în rândul celor care nu au „niciun prieten”. Într-o discuție cu domnul Alexandru, patronul cârciumei „Tanzit”, „fost intelectual” și „viitor fost dizident”, despre principiile oamenilor de presă și despre starea lucrurilor în timpul „regimului” și după, Jean își amintește de „evoluţia” sa, pomenind, de altfel, „de funie în casa spânzuratului”: „Aşa cum eu sunt ziarist şi fost ziarist, am un prieten care lucrează într-un serviciu secret şi ÎNAINTE a lucrat la Securitate. (...) după revoluție - eram eu necăjit pentru că pierdusem apartamentul la primul divorț - îl văd într-o împrejurare: lucra încă «în aparat», dar făcea şi afaceri pe cont propriu, cred. Aşa, îşi folosea din plin vechile relaţii. Acum afacerile externe nu mai sunt asistate de Securitate, de asta nu se descurcă directorii din vechea generație; pardon, «managerii»- că aşa le place să-şi spună! Aşa că, în mare nevoie fiind, m-am dus la fostul meu «torţionar» şi l-am rugat să mă ajute... Acum am casă! (...) Nu prea ne spunem secretele. Ştiți, deviza lui a fost şi este: «AM UN PRIETEN CARE N-ARE NICI UN PRIETEN!»...

ALEXANDRU: Spionul are, se ştie, ochii reci, pielea de şopârlă, inima din beton armat şi degetul sudat pe trăgaci. A omorât prietenul tău mai mulți oameni decât am omorât eu în romanele mele? Nu cred!" 53. Dorința celui din urmă de a deține un ziar, „liber cum nu s-a văzut”, subliniază încă o dată rolul important al mass-mediei, dar într-un sistem corupt. Conducerea unei publicații avea să-i asigure „toată” puterea, întrucât „prefectul o să oprească maşina pe stradă,

${ }^{51}$ Ibidem, p. 44 , s. a.

52 „Se ia o boabă de piper (...) se înveleşte într-o feliuță de slăninuță (...) Bagi totul într-o prună uscată ca o carte veche (...) Pruna o ascunzi bine într-o prepeliţă (...) O introduci, împreună cu ierburi vrăjitoreşti şi mirodenii diferite în burta unei puici dolofane (...) Se bagă totul într-un miel, pe care-l înfigi într-o frigare de lemn (...) Când carnea s-a copt, mai aştepți preț de o rugăciune. Apoi, desfaci totul: miel, găinuşă, prepeliţă... Deschizi cu grijă pruna şi... mănânci numai boaba aia de piper...", în Victor Cilincă, Paparazzi. Polonius, Editura Dominus, Galați, 1999, pp. 51-52.

${ }^{53}$ Ibidem, p. 27. 
primarul o să-şi scoată pălăria în fața mea"54. După o suită de știri ce influențează evenimentele din oraș (spitalele se închid și se deschid în funcție de articole), de deconspirări (operația „estetică” a primarului), și de răsturnări de situații, acesta îi vinde lui Elvis Romanescu afacerea cu iz bahic și își îndeplinește „visul”. Dacă Gigi crede că printr-un organ de presă se poate face dreptate, Geta, mai realistă, puncteză: „Domnişoară, Dreptatea umblă spartă la cap!”55. Astfel, lupta pentru „monopol”, purtată în principal prin dezvăluiri de secrete, se dă în paginile revistelor „Media” și „Atacul”. Pretenţiile de „mare scriitor" neîntinat ale lui Alexandru sunt "aduse la esență” de schimbul de replici dintre Gigi și Elvis:

„ELVIS: (...) Da' bătrânu' lu matale de unde are banu' pă el?

GIGI: - A câştigat bine, chiar foarte bine înainte de '89, din spionaj...

ELVIS: - Că chiar că ne-am dus dracului dă suflet, dac-am ajuns să spunem acu' pă şleau chestii d-ăstea!" 56 . Circularitatea piesei, ținând cont de scena inițială și cea finală, dezvăluie o „stagnare umană” generală, căci „totul avea să fie cum a mai fost". Singurele elemente ce indică trecerea timpului sunt apariția de reviste străine pe care le răsfoiește Geta și atârnarea anunțului îngălbenit în cârciumă, „ÎN ACEASTĂ UNITATE NU SE ÎNJURĂ!". Limitarea încifrată condiției personajelor lui Vișniec nu poate produce schimbări universului „în destrămare", în care se anunță că soarele nu va mai răsări. În afară de neînțelesul Orb care sună la telefoane publice pentru a vorbi cu oameni și pentru a vedea „un afară” prin ochii altora și în afară de Omul străzii care nu-i vinde acestuia medalionul cu poza mamei, singurul care mai este mișcat de „existență” rămâne doar animatul Automat cu băuturi: „Dumnezeule... Și totuși cât e de frumos!" 57 .

Punerea „față în față” a celor două texte dramatice conduce la observarea unei întregi serii de corespondențe la nivel tematic. În textul lui Vișniec, a cărui structură amintește de modulele sale teatrale, „dialogul” este fie inexistent sau defectuos, fie respins:

„Omul cu cutia de saxofon: Dumneavoastră sunteți patroana?

Patroana (total absentă): Cum?

\footnotetext{
${ }^{54}$ Ibidem, p. 11.

55 Ibidem, p. 15.

56 Ibidem, pp. 21-22.

${ }^{57}$ Matei Vișniec, Paparazzi sau Cronica unui răsărit de soare avortat, Editura LiterNet, 2002, p. 80 .
} 
Omul cu cutia de violoncel: Era o intersecție, aici, chiar lângă cafeneaua dumneavoastră...

Patroana: Unde?

Omul cu cutia de violoncel: Acolo, unde-i câinele. De fapt, al cui e?

Patroana: Cine?! (...)

Omul pentru care nașterea a fost o cădere (disperat): A, nu, nu... Așa nu merge... (plecând) Nici măcar nu mă ascultați... ce dracu'... (...)

Vocea: Și soarele?

Bărbatul cu cutia de flaut: Și soarele, ce?

Vocea: Soarele... cum e cu soarele?

Bărbatul cu cutia de flaut: Soarele, cum e cu soarele, ce?

Vocea: Soarele se vede?

Bărbatul cu cutia de flaut: Stimate domnule, ia mai duceți-vă dracului!"58.

În piesa lui Cilincă, în loc să comunice „autentic”, personajele mai mult "șuşotesc", „clevetesc", spun banalități, mint sau divaghează, pentru a-și ascunde adevărata „față”. În ciuda acestei tendințe manifestate la nivelul "dialogului", acțiunea nu este „,tinută în loc":

„GETA (încet): Da' ce moaş'ta vrei de la ora opt? Te arde gâtu'? (...)

ELVIS (plictisit de conversaţia pe care n-o înţelege, către Geta): Domna Geta, mâncaţi-aş muzicuţa, da' matale ştii să găteşti? (...)

GETA (se aşează la masă şi şuşoteşte cu Gigi): Ba mai degrabă aş băga divorţ. Al meu e şomer, şade acasă şi mă gelozeşte (...)

JEAN (îngrijorat): Ce să caute la primar? Zicea că nu facem pace!

MUTU' (insinuant): S-o fi dus să spună că n-a scris el articolul cu țevile!

JEAN (ameninţător, îl ridică de revere): Ai aerul că ştii cine l-a scris, ai?!

MUTU': Ştiu: Moş Gerilă, când l-a dat afară Moş Crăciun!

JEAN (şuierând): Aşa, copăcel!

GETA: Ce mai faci, musiu, nu saluţi cucoanele? Măcar pe mine, că sunt patroană! $\mathrm{Cu}$ banii soţului meu iese şi jumate de ziar!

JEAN (încă nervos): Şi nu-i fac eu editorialul? El face partea cea mai grea: îl semnează. Ce oboseală!

GETA: Vezi că eşti mojic? Eu te-am întrebat ce faci!

JEAN: Fac pluta, doamnă"59. Una dintre puținele secvențe ce ilustrează contrariul vizează dialogul dintre medicul psihiatru Gigi și „prea tânărul” preot. Cu conștiința încărcată, femeia simte nevoia de a vorbi, de a-și mărturisi,

${ }^{58}$ Ibidem, pp.: 9, 21, 53.

59 Victor Cilincă, Paparazzi. Polonius, Editura Dominus, Galați, 1999, pp.: 11, 17-18, 20, 43. 
printre altele, și incapacitatea de a iubi. Cu toate acestea, ajunge să asculte tulburările interioare ale „părintelui” ce pusese mâna pe armă la revoluția din 1989:

„GIGI: Vezi, se pare că eu te-am spovedit pe dumneata. De ani de zile visez să mă asculte şi pe mine cineva. Să vorbesc, să vorbesc despre tot şi toate, iar el, omul acela, să-şi mai aprindă o țigară şi să se uite în continuare la buzele mele... Şi, din când în când, să-mi strângă mâna, în semn de înțelegere...

PĂRINTELE: Vedeți, eu nu fumez..." ${ }^{60}$.

Apropierea dintre oameni nu este determinată de trăiri, ci de interese. Dacă Geta scapă de condiția de barmaniță devenind „patroană” prin concubinajul cu Elvis, Jean Marmeliuc publică în presă sub altă semnătură anumite secrete „scăpate” de Gigi într-un cadru intim: „(...) domnul ziarist (...) se luptă cu limba cea despicată. El este un mestru al stilului curat-murdar, cu exprimare aparentclară, dublu sens. (...) Omul ăsta trebuie să dea socoteala într-o zi, părinte. Nu se face disecție pe om viu şi nici nu pui sufletul omului pe tarabă, oricine ar fi el. Ori, el a făcut disecţie pe mine, în timp ce mă mângâia... Unii ziarişti o fac!"61 (Gigi). Traumele își pun amprenta asupra destinelor, căci, dacă preotul nu mai poate confesa, femeia ajunge un fel de Mata Hari, vânzând „cunoștințe" pentru a se răzbuna: „Cred că uneori suntem cu toții nişte paparazzi..." ${ }^{62}$. Asemenea, în piesa lui Vișniec, Paparazzo 1 relaționează cu vedeta pe care o „urmărea”, pentru a-și face datoria. La petrecerea haotică organizată de aceasta, participă flautistul, omul cu violoncelul. dar și bărbatul cu un walkman pe urechi. In/evoluția lor ulterioară, inclusiv a Femeii desculțe, poate fi pusă pe seama desfrâului general.

În astfel de cadre, nebunia și alienarea nu aveau cum să lipsească. Dacă în urma discuției cu Patroana de cafenea, Omul cu cutia de violoncel decide: „Hai să ne cărăbănim. Toți sunt nebuni”63, alți senili își găsesc locul în spitalul unde lucrează Gigi. Pe lângă „un Petru Groza” ce are tendința de a naționaliza „tot ce prinde" și pe lângă „un Napoleon”, în fișele medicale sunt consemnați mai mulți de-alde „Ceaușescu”: „Unul, de pildă, se dădea drept agent secret şi a lățit zvonul că Ceauşescu trăieşte şi caută gazdă (Ceauşescu!), în aşteptarea conturilor din străinatate. Că nea Nicu are de gând să se întoarcă. Sau să candideze; tot cam aia... Ei bine, săracu', nu mințea: chiar avem un «Ceauşescu»

${ }^{60}$ Ibidem, p. 35.

${ }^{61}$ Ibidem, pp.: 25, 35.

62 Ibidem, p. 49.

${ }^{63}$ Matei Vișniec, Paparazzi sau Cronica unui răsărit de soare avortat, Editura LiterNet, 2002, p. 13. 
la balamuc... de fapt, doi sau chiar trei. Dar dacă or emite şi ăilalţi pretenţii, se produce dracului inflaţie şi fraierii n-or să-l mai creadă pe nici unul. Urmarea: se duce dracului şi de tot comunismul, nu? (...) O lume de nebuni! Cu toţii suntem nebuni, numai că unii ne mai dăm şi seama! Şi cum să nu-nnebuneşti, când ne conduc tot felu' de anormali?"64. Forțând „descreierarea”, în textul lui Matei Vișniec „își pierd mințile” și obiectele: „Au înnebunit trenurile, o locomotivă scăpată de sub control a intrat ca în brânză în holul gării centrale, paf!"65.

În ciuda denumirii cârciumei „Tranzit”, spațiul municipal desemnează un univers închis, limitat, tocmai prin micimea caracterelor. După ce scrie fără cruțare despre cel ce era tatăl său, Jean Marmeliuc simte că „,a terminat” pe plan local și că trebuie să se îndrepte către București. În slujba țiganului Elvis, Albu' manifestă nerăbdare: „Cu tranziţa-i şi mai greu, că asta n-o să se termine niciodată... Ca s-apuc să fiu şi eu patron, să am şi eu «negrii» mei..." ${ }^{66}$. Vizânduse sugerarea „uitării generale” ce se așterne peste societate, didascaliile propun ca imaginea cimitirului „de altădată” să fie reprezentată scenic în fața unei cortinei trase: „Aici nu mai e cimitir, doamnă. Aici începe pământul Consiliului municipal (...). Va trebui să facă un gard între noi... (Părintele)"67. Similar se întâmplă și în textul lui Vișniec. Intersecția din fața cafenelei dispare. Lacul cu rațe descris Orbului lasă locul unei stații de autobuz înconjurate de o câmpie, fără niciun copac. Bărbatul și Femeia care voiau să plece cu trenul nu mai au unde, căci gara se închide. Cu toate acestea, ei tot își cumpără bilete. Femeia cu busola este dezorientată, asemenea Femeii desculțe ce rătăcește prin oraș „,ca o fantomă".

În Paparazzii lui Cilincă, pierderea identității se remarcă, cu deosebire, în cazul anumitor „amăriți” care frecventează barul. Astfel, cu personalitatea știrbită, fără nume, unui consumator avea să i se spună Domnu' Cavou, după locul în care „,̂și ducea zilele”. Descrierea situației acestuia nu îl emoționează pe Alexandru, căci, fals compătimitor, exclamă: „Țî̀-țîtțî... Săracu' (...) ! Aşa făcea şi Partidu' cu coloana vajnicilor noştri scriitori. Era mai dureros şi tot în alcool se înneca durerea..."68. Ca într-un schimb de roluri Pygmalion - Galateea,

\footnotetext{
${ }^{64}$ Victor Cilincă, Paparazzi. Polonius, Editura Dominus, Galați, 1999, p. 16.

${ }^{65}$ Matei Vișniec, Paparazzi sau Cronica unui răsărit de soare avortat, Editura LiterNet, 2002, p. 27.

${ }^{66}$ Victor Cilincă, Paparazzi. Polonius, Editura Dominus, Galați, 1999, pp. 53-54.

${ }^{67}$ Ibidem, p. 30.

${ }^{68}$ Ibidem, p. 11.
} 
„plăsmuirea” bărbatului „fără memorie” de către Gigi eșuează prin moartea acestuia:

„GIGI: (...) dintr-o necuvântătoare ținută în cămaşă de forţă, cu tranchilizante, am făcut un om CARE PUTEA SĂ OPTEZE? Liber! Dar ATUNCI nu puteai să optezi liber în România... (...)

PĂRINTELE: - Spuneaţi că a murit într-un accident. Nu sunt psihiatru, dar să ştiţi că am mai citit câte ceva: poate este vorba despre un complex de vinovătie? Erați la volan, sau... Acestea sunt imagini care te urmăresc toată viaţa... Poate că era sub ochii dumneavoastră atunci când l-a călcat o maşină...

GIGI: - Nu, l-a călcat un tanc.

PĂRINTELE: - Glumiți...

GIGI: - NU, l-a călcat un tanc - tanc! Mihai s-a dus şi el la Revoluţie, cu noua conştiinţă, pe care i-o fabricasem eu din cărţi şi manuale!"69. Pentru toate celelalte figuri, statutul profesional sau dorința de parvenire înlocuiesc esențialele resorturi interioare. La Vișniec, ștergerea „propriei voci” este indicată încă din lista de persoane, prin atribuirea de nume generice (Străinul, Casierul, Femeia desculță etc.). Conținutul piesei nu face decât să accentueze aceste tipologii umane secate de "eu”, lipsite de "muzicalitate”: Omul cu cutia de violoncel, Omul cu cutia de saxofon, Bărbatul cu cutia de flaut. $\mathrm{Cu}$ toate acestea, (pre)nume apar sporadic, doar în interiorul replicilor. Cei doi paparazzi sunt, pentru Șef, Mario și Toni, Orbul devenind domnul Bessou pentru Omul străzii, Mimil. Arderea papetăriei de oameni cărora „le cedaseră nervii”, asociată cu identificarea „adevăratei” literaturi cu cea de consum, nu face altceva decât să întărească o aneantizare spirituală. Revenind la Cilincă, preocuparea pentru „arta cuvântului" și „protejarea” limbii literare de către domnul Alexandru, după cum o cerea anunțul din bar, se realizează în următorul fel: „«Banii», nenorocito, «banii», nu «lovelele», nu «mardeii», nu «biştarii», baragladină postmodernistă ce eşti! Am să purced la alfabetizare forţată cu tine aşa cum a făcut pecereul cooperativizarea: convingându-i pe țărani de binefacerile agriculturii socialiste, cu arma în mână!"70. În Cronica unui răsărit de soare avortat, existența este deplânsă de Omul pentru care nașterea a fost o cădere, „o prăbușire”, căci, asemenea copilului „născut” - de această dată - al lui Virgil Tănase ${ }^{71}$, meditează și „lovește”: „Știți, eu mi-am pus foarte des întrebarea... Ce

\footnotetext{
${ }^{69}$ Ibidem, p. 34.

${ }^{70}$ Ibidem, p. 10.

${ }^{71}$ V. Virgil Tănase, Teatru, Editura Eminescu, București, 1996 (Copilul acestui secol extraordinar).
} 
este, de fapt, nașterea? Ei bine, nașterea este înainte de toate un strigăt. Un strigăt care te propulsează în mod brutal dintr-o lume în alta. Dintr-o stare sufletească în alta. Dintr-o viaţă în alta. (...) Apoi... începe angoasa... stresul... neputința... timpul... așteptarea... Repetarea obsedantă a anumitor gesturi. A anumitor cuvinte. A anumitor senzații. Care te hărțuiesc la infinit. Pentru că apoi trăiești sub semnul durerii. (...) Da, este vorba de durerea pe care ți-a inoculat-o expulzarea din pântecele mamei tale. (lovește). O expulzare pe care o numim naștere. (lovește). Și la care nu te așteptai. Și pe care n-ai dorit-o. (lovește). Și pe care n-ai acceptat-o. Și care ți-a rănit toată ființa..."72. Refuzul, neacceptarea „nașterii” mai sus punctate capătă dimensiuni cosmice prin „avortul răsăritului de soare". Jucându-se cu temporalitea de-a lungul celor 14 scene (scurgerea timpului, de la 8 seara la 8 dimineața, putând fi sugerată prin varii modalități regizorale libere), în ultima secvență textuală, ce propune, de altfel, un final deschis, Vișniec suspendă „orologiul”, dând, astfel, umanității timp „de gândire".

Sondând conștiințe de după '89, Cilincă „,scapă” pe alocuri replici ce pot fi suspectate de biografism. Dacă Părintele afirmă că „ş̧coala comunistă i-a îndobitocit pe oameni şi L-a scos pe Dumnezeu din mulţi"73, Jean are o intervenție ce exprimă o latură sensibilă, prea puțin dezvoltată de-a lungul piesei: „În meseria asta eşti crucificat între diplomâ̂ie şi starea de paparazzi. Cuvintele se cântăresc cu balanţa analitică, o virgulă poate nenoroci un om sau te poate salva de puşcărie, ghilimelele sunt cel mai bun avocat! Eu am lucrat şi pe vremea cealaltă, a comunismului, când te bucurai şi de o virgulă pusă aluziv... Se spunea: «deosebirea între ziaristul român şi cel american este ca românul este liber să scrie despre ce vrea... dar americanul este liber şi după aia!» Ei bine, n-ai fi apucat să publici «ceva» în clar, oricât de viteaz ai fi fost! E ca şi cum scoteai o ediţie de un exemplar, pe care te-ar fi forțat să-l înghiţi imediat. Şi, chiar dacă s-ar fi întâmplat să scape «ceva» în ziar, era destituită conducerea ziarului, dați afară colegii... Ştii câte telefoane de ameninţare primeai de la «simplii cetățeni», vigilenți, dacă capul limpede de la ziar scăpa o greşală de genul «Ceaucescu» în loc de «Ceauşescu»?!... Rămânea doar satisfacția aluziilor strecurate şi faptul că instituţiile din județ dădeau socoteală ziarului, atunci când se călca pe bec, când se făcea o nedreptate..."74. Posibila sa

\footnotetext{
${ }^{72}$ Loviturile sunt îndreptate către Omul legat în sac. 52-53

${ }^{73}$ Ibidem, p. 31.

${ }^{74}$ Ibidem, pp. 52-53.
} 
moarte din final, într-un „accident”, marchează și resemnarea lui Gigi în fața compromisurilor, pentru a putea „supraviețui".

Piesa rămâne, totuși, o comedie, una „tragică”, după cum este precizat și paratextual, de-a lungul textului umorul „negru” conturând crepusculul unei lumi: „Dom' Cavou, te-a ajuns puterile? Marş în cimitir, la nani-nani!”75 (Geta). Comicul de limbaj îl definește pe cel de situație, căci, spre exemplu, discutânduse despre situația lui Fane (Spoitoru'), se evidențiază, într-o îmbinare a liricului cu dramaticul, cursul nefiresc al societății, în particular, al omenirii, în general: „GETA (mic frison): Nu pleacă Fane acu' din România, că-n România acu' e bine!

ALBU': Pe Fane-1 dobori doar cu glonț dă argint; în România nu mai e gloanțe de argint! (Din off: «Să le dea Domnul dă bine / Că au tras cu gloanțe-n mine / De vuise-ntreaga țară / Că nu sunt om, că sunt fiară.»).

GIGI: Ce viguros se dezvoltă şi azi literatura populară!"76.

Dacă implozia solară, definită de profesorul Pandolfi ca un soi de „prăbușire a materiei în ea însăși”, determinată, s-ar părea, de un agent venit „din exterior", ar presupune un răsărit puțin probabil77, mesajele venite din partea municipalității frizează ridicolul, pe lângă evidențierea absurdului existențelor imaginate. Negările par a funcționa dacă nu „invers”, cel puțin ironic: „Nu uitați că suntem ființe civilizate, rămâneți închiși în locuințele dumneavoastră, nu ieșiți pe străzi... (...) nu uitați că avem o conștiință, economisiți apa și electricitatea... (...) Noi nu suntem animale... Noi nu suntem dobitoace... Noi nu suntem mongoloizi... Noi nu suntem bolnavi mintal... Noi nu suntem avortoni... Noi suntem ființe omenești demne..."78.

Exprimându-și părerea privind „făurirea personajului" și rolul său în teatru, Valentin Silvestru preciza că o cercetare paralelă, chiar și în diversitate, „va surprinde totdeauna echivalențe între felul cum s-a pus problema omului (...) și modul în care a rezolvat-o arta"79. Astfel, pornind de la experiențe proprii sau de la evenimente "cu impact”, cei doi dramaturgi au creat piese având în

75 Ibidem, p. 13.

${ }^{76}$ Ibidem, pp. 39-40.

77 V. Matei Vișniec, Paparazzi sau Cronica unui răsărit de soare avortat, Editura LiterNet, 2002, pp.

43-44.

${ }^{78}$ Ibidem, p. 44.

${ }_{79}$ Valentin Silvestru, Personajul în teatru, Editura Meridiane, București, 1966, p. 24. 
centru un "om al acestor zile" 80 , un caracter "generalizator" care, lipsit de umanitate, ajunge să ducă, după o „stingere de sine”, la un „apus de lume”. Numitul paparazzo devine exponent al unei „bucăți de istorie”. Semnalând „răul existențial” prin istoria unor personaje cu identități șterse, mutilate sau în curs „,de distrugere”, operele de teatru au ca miză resurecția umană.

Analiza a condus la observarea faptului că, deși stabiliți în spații diferite, preocupările artistice, teatrale converg. Cu toate acestea, în ciuda „locurilor comune”, conținutul, stilul și, de ce nu, „măiestria artistică” individualizează fiecare operă, fiecare autor, în parte.

\section{Bibliografie}

\section{Corpus}

Cilincă, Victor, Odiseea pentru uz intern - roman despre viaţa marinarilor -, Ed. Logos, Galați, 1997.

Cilincă, Victor, Paparazzi. Polonius, Editura Dominus, Galați, 1999.

Vișniec, Matei, Paparazzi sau Cronica unui răsărit de soare avortat, Editura LiterNet, 2002.

Vișniec, Matei, Cronica ideilor tulburătoare, Editura polirom, București, 2010.

Vișniec, Matei, Omul din care a fost extras răul, Editura Cartea Românească, București, 2014.

\section{Volume de istorie și de critică literară}

*** Dialogul neîntrerupt al teatrului în secolul XX (vol. I, De la Caragiale la Brecht; vol. II, De la Lorca la Brook), București, Editura Minerva, 1973.

Banu, George, Ultimul sfert de secol teatral. O panoramă subiectivă, trad. de Delia Voicu, Editura Paralela 45, București, 2003.

Băicuș, Iulian, Critici literari români din diaspora, Editura Virtual, București, 2013. Ghițulescu, Mircea, Istoria literaturii române. Dramaturgia, Editura Academiei Române, București, 2007.

Silvestru, Valentin, Personajul în teatru, Editura Meridiane, București, 1966.

80 V. Matei Vișniec, Paparazzi ou La Chronique d'un lever de soleil avorté. Critiques, disponibil online: http://www.visniec.com/pages/paparazzi.php. 


\section{Periodice}

Boboiciov Magiaru, Daniela, Interviu cu Matei Vișniec. Utopia si practica. Un raport pervers, în Orizont, Nr. 1, ianuarie 2007, disponibil online: http://www.romaniaculturala.ro/articol.php?cod=7548.

Morariu, Mircea, Cronică de teatru: Un clar-obscur multisemantizat, în Adevărul, 1 martie 2013, disponibil online: http://adevarul.ro/cultura/teatru/cronica-teatruclar-obscur-multisemantizat-1 5130b4f200f5182b85b9512d/index.html

Popovici, Iulia, Lecturi la zi: Din nou, Vişniec, în România literară, nr. 44, 2002, disponibil online: http://www.romlit.ro/din nou viniec.

Trandafir, Constantin, Prozatorul Victor Cilincă, în Porto-Franco, nr. 228, Galați, 2015.

Țuca, Marius, Emoții și elogii pentru Victor Cilincă, în Viața liberă, Galați, 2 iunie 2009, n. a., disponibil online: http://www.viata-libera.ro/vlg-cultura/6372-emotiisi-elogii-pentru-victor-cilinca.

Vișniec, Matei, Paparazzi ou La Chronique d'un lever de soleil avorté. Présentation, disponibil online: http://www.visniec.com/pages/paparazzi.php.

*** Corespondență (2015). 